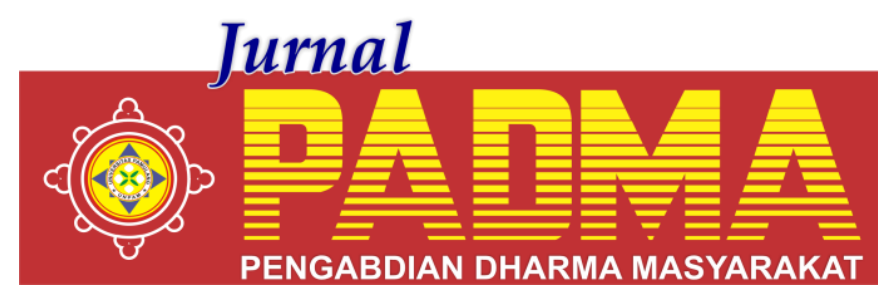

VOLUME 1, NOMOR 3, JULI 2021

\title{
PELATIHAN STRATEGI BERSAING SUMBER DAYA MANUSIA DI ERA 5.0 PADA MASYARAKAT DESA
}

\author{
1*Bayu Dwi Prasetyo, 2Erisza Pandu Pranata, 3Isa Meydina, 4Sya'diatul Jannah, \\ 5Zainun Nur Fauzi \\ Universitas Pamulang, Tangerang Selatan, Banten, Indonesia \\ *dosen01098@unpam.ac.id
}

\begin{abstract}
Abstrak
Pelatihan strategi bersaing Sumber Daya Manusia di era 5.0 pada masyarakat desa diharapkan masyarakat desa Cidokom dapat memiliki kompetensi lainnya yaitu mampu berpikir kritis, bernalar, kretatif, berkomunikasi, kolaborasi serta memiliki kemampuan problem solving atas perkembangan industri di Era 5.0. Tujuan dari pelatihan strategi bersaing Sumber Daya Manusia di era 5.0 diharapkan dapat menghasilkan Sumber Daya Manusia unggul dengan beradaptasi di era society 5.0.
\end{abstract}

Kata Kunci : Pelatihan, SDM, Society 5.0

Abstract
Competitive strategy training for Human Resources in the 5.0 era in rural communities is expected to have other competencies in Cikodom village, namely being able to think critically, reason, be creative, communicate, collaborate and have problem solving skills for industrial development in Era 5.0. The purpose of training on competitive strategies for Human Resources in the 5.0 era is expected to produce superior Human Resources by adapting in the era of society 5.0.

Keywords: Training, Human Resources, Society 5.0

\section{PENDAHULUAN}

Pengabdian masyarakat adalah suatu kegiatan yang bertujuan membantu masyarakat tertentu dalam beberapa aktivitas tanpa mengharapkan imbalan dalam bentuk apapun. Secara umum program ini dirancang oleh berbagai universitas atau institut yang ada di Indonesia begitu pula di Universitas Pamulang (UNPAM) untuk memberikan kontribusi nyata bagi bangsa Indonesia, khususnya dalam mengimplementasikan kadar lingkungan kepada Masyarakat.

Dalam menghadapi era society 5.0 , dunia pendidikan berperan penting dalam meningkatkan kualitas SDM. Selain pendidikan beberapa elemen dan pemangku kepentingan seperti pemerintah, Organisasi Masyarakat (Ormas) dan seluruh masyarakat juga turut andil dalam menyambut era society 5.0 mendatang.

Merdeka belajar juga dapat dimaknai dengan kebijakan strategis baik pemerintah maupun swasta dalam mendukung implementasi merdeka belajar, prosedur akreditasi yang dapat beradaptasi, sesuai kebutuhan oraganisasi/lembaga/sekolah, serta pendanaan pendidikan yang efektif dan akuntabel salahsatunya ditandai dengan otonomi satuan pendidikan dalam penyelenggaraan pendidikan. Oleh karena itu, penulis ingin melakukan pengabdian masyarakat dengan tujuan memberikan gambaran dan strategi apa saja yang harus di persiapkan dalam menghadapi Era 5.0 yang dilakukan ini berjudul "Pelatihan Strategi Bersaing SDM di Era 5.0 Pada Masyarakat Desa " Pengabdian ini kami lakukan di Desa Cikodom, Kec. Gunung Sindur, Kab Bogor, Jawa Barat.

Sumber daya manusia (SDM) adalah salah satu faktor yang sangat penting bahkan tidak dapat dilepaskan dari sebuah organisasi, baik institusi maupun perusahaan. SDM juga merupakan kunci yang menentukan perkembangan perusahaan. Pada hakikatnya, SDM berupa manusia yang dipekerjakan di sebuah organisasi sebagai penggerak, pemikir dan perencana untuk mencapai tujuan organisasi itu. 
Pengertian SDM dapat dibagi menjadi dua, yaitu pengertian mikro dan pengertian makro. Pengertian SDM secara mikro adalah individu yang bekerja dan menjadi anggota suatu perusahaan atau institusi dan biasa disebut sebagai pegawai, buruh, karyawan, pekerja, tenaga kerja dan lain sebagainya. Sedangkang pengertian SDM secara makro adalah penduduk suatu negara yang sudah memasuki usia angkatan kerja, baik yang belum bekerja maupun yang sudah bekerja.

Sehingga secara menyeluruh, pengertian Sumber Daya Manusia adalah individu yang bekerja sebagai penggerak suatu organisasi, baik institusi maupun perusahaan dan berfungsi sebagai aset yang harus dilatih dan dikembangkan kemampuannya.

Perencanaan SDM merupakan proses pengambilan keputusan dengan memperhatikan kemahiran dan pemanfaatan SDM. Hal ini sebagai proses penentuan keputusan strategis. Perencanaan SDM berfokus pada analisis tujuan perusahaan. Sementara perencanaan membutuhkan sumberdaya untuk memenuhi tujuan tersebut. Tujuan perusahaan dan kebutuhan sumber daya dianalisis dalam kaitanya

Perencanaan SDM adalah jumlah dari seluruh rencana yang diformulasi untuk pelatihan, promosi, dan aturan main dari SDM. Ia merupakan sebuah proses yang dirancang untuk menerjemahkan rencana perusahaan dan tujuan kedalam syaratsyarat pekerjaan. Halini dilakukan bersama dengan rencana memenuhi persyartan jangka pendek dan panjang melalui pemanfaatan SDM, pengembangan SDM, pekerjaan, dan penggunaan sistem informasi. Pelatihan (training) adalah proses pendidikan jangka pendek yang menggunakan prosedur sistematis dan terorganisir sehingga tenaga kerja non manajerial mempelajari pengetahuan dan keterampilan teknis untuk tujuan tertentu. Pelatihan kerja menurut undang-undang No. 13 Tahun 2003 pasal 1 ayat 9. adalah keseluruhan kegiatan untuk memberi, memperoleh, meningkatkan, serta mengembangkan kompetensi kerja pada tingkat ketrampilan dan keahlian tertentu sesuai dengen jenjang dan kualifikasi jabatan dan pekerjaaan.
Menurut Marzuki pelatihan adalah pengajaran atau pemberian pengalaman kepada seseorang untuk mengembangkan tingkah laku (pengetahuan, skill, sikap) agar mencapai sesuatu yang di inginkan. Pelatihan bagi karyawan merupakan sebuah proses mengajarkan pengetahuan dan keahlian tertentu serta sikap agar karyawan semakin terampil dan mampu melaksanakan tanggung jawabnya dengan semakin baik.

Pengembangan (development) memiliki arti yaitu suatu proses pendidikan jangka panjang yang mempergunakan posedur sistematis dan terorganisasi dimana pegawai manajerial mempelajari pengetahuan konseptual dan teoritis guna mencapai tujuan yang umum.

Pengembangan sumber daya manusia yaitu kegiatan yang harus dilakukan oganisasi agar pengetahuan (knowledge), kemampuan (Ability), dan ketrampilan (skill) mereka sesuai dengan ketentuan pekejaan yang dilakukan.

Pengembangan merupakan proses mendapatkan pengalaman, keahlian, dan sikap meraih sukses dalam organisasi. Hal ini tentu memunculkan tindakan untuk melakukan kegiatan belajar secara terus menurus.

\section{METODE}

Metode pelaksanaan pengabdian kepada masyarakat ini diawali dengan melakukan peninjauan lapangan dan koordinasi dengan panitia. Metode kegiatan pengabdian kepada masyarakat yang digunakan adalah metode presentasi, tutorial, tanya jawab, dan diskusi yang dipilih untuk menyampaikan materi kepada warga Desa Cidokom. Pemanfaatan pengeras suara membantu peserta pelatihan lebih mudah memahami dan mendengar materi pelatihan dengan jelas dengan waktu pelatihan yang terbatas.

Karena kegiatan Pengabdian Kepada Masyarakat ini dilakukan pada saat pandemi Covid-19, maka sebagai masyarakat indonesia yang baik kita harus bisa menjaga lingkungan kita sendiri dengan baik dengan cara mengikuti protokol kesehatan anjuran menteri kesehatan dengan menggunakan masker dengan benar, mencuci tangan dengan sabun serta menjaga jarak, dan peserta pelatihan yang kita undang juga 
terbatas agar terhindar dari bertambahnya jumlah kasus Covid-19.

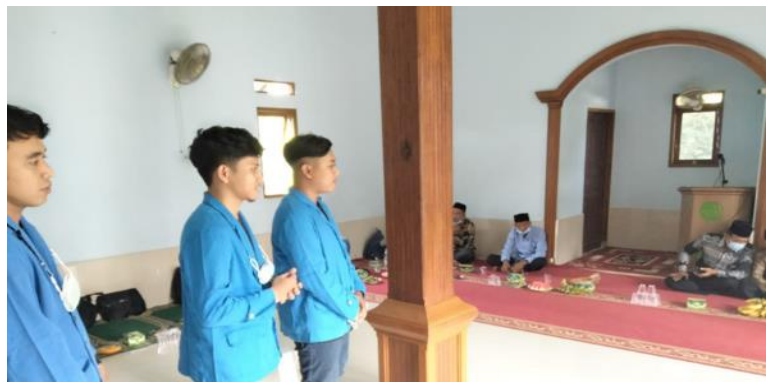

Gambar 1. Penyampaian dengan metode presentasi

\section{HASIL DAN PEMBAHASAN}

Tempat pelaksanaan kegiatan

Pengabdian Kepada Masyarakat (PKM) Di Jalan SDN Melati RT 002 RW 03, Desa Cidokom, Kecamatan Gunung Sindur, Kabupaten Bogor, Provinsi Jawa Barat . Adapun waktu pelaksanaan dari kegiatan Pengabdian Kepada Masyarakat di laksanakan pada tanggal 11 April 2021.

Output yang diharapkan adalah bahwa masyarakat desa Cikodom tidak hanya literasi dasar namun juga memiliki kompetensi lainnya yaitu mampu berpikir kritis, bernalar, kretatif, berkomunikasi, kolaborasi serta memiliki kemampuan problem solving. Dan yang terpenting memiliki perilaku (karakter) yang mencerminkan profil pelajar pancasila seperti rasa ingin tahu, inisiatif, kegigihan, mudah beradaptasi memiliki jiwa kepemimpinan, memiliki kepedulian sosial dan budaya. Karena dalam menghadapi Era 5.0 ini kita tidak boleh melupakan budaya yang kita miliki.

Era society 5.0 tantangannya adalah kesiapan SDM akibat belum sepenuhnya mampu menguasai teknologi informasi, sehingga pemerintah kecamatan dan desa sejak saat ini, mulai mempersiapkan diri meningkatkan pengetahuan teknologi informasi. Era society 5.0 seluruh teknologi penginderaan, robotika, komunikasi, dan big data akan menyatu menjadi solusi untuk berbagai masalah yang sebelumnya dianggap tidak dapat terpecahkan, termasuk juga dalam meningkatkan pembangunan desa. Maka dari itu penerapan SDM yang perlu dilakukan yaitu :
1. Hasil pengabdian masyarakat ini diharapkan dapat merubah paradigma masyarakat desa Cikodom atas perkembangan industri di Era 5.0.

2. Hasil pengabdian masyarakat ini diharapkan masyarakat desa Cikodom dapat memiliki kompetensi lainnya yaitu mampu berpikir kritis, bernalar, kretatif, berkomunikasi, kolaborasi serta memiliki kemampuan problem solving.

3. Hasil pengabdian ini diharapkan dapat Menghasilkan SDM unggul dengan beradaptasi di era society 5.0.

4. Pelatihan dan pengembangan SDM

Pemberian training yang dimaksudkan untuk meningkatkan masyarakat desa sehingga dapat menghasilkan hasil yang positif secara signifikan, maka pelatihan didasarkan pada kompetensi masing-masing individu. Dengan begitu, strategi yang disusun akan jauh lebih fokus dan terarah sesuai dengan kebutuhan.

5. Pemberian penghargaan

Tanpa adanya masyarakat desa
yang mau untuk belajar tentang penggunaan internet, dan lainnya, pasti pada masyarakat desa akan semakin tertinggal dan tidak bisa berjalan dengan baik. SDM kompeten dan berkualitas tentu menjadi aset kebanggaan. Sebagai timbal balik dari kontribusi yang diberikan, perusahaan dapat menawarkan penghargaan dan remunerasi kepada pegawai yang berhak dimana umumnya penilaian dilakukan berdasarkan kompetensi masing-masing individu.

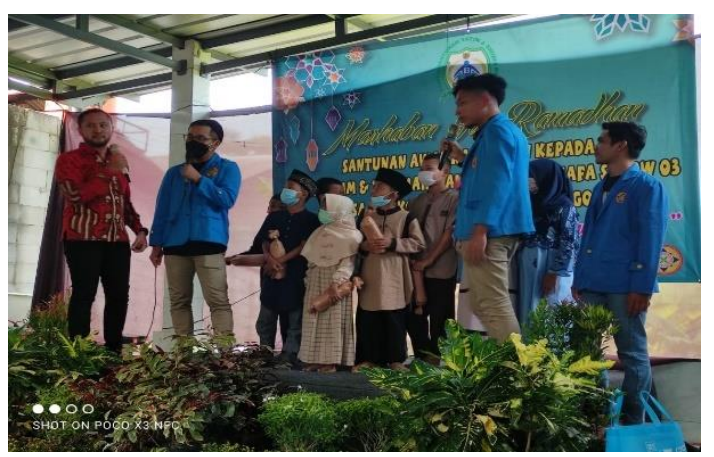

Gambar 2. Kegiatan sesi tanya jawab 


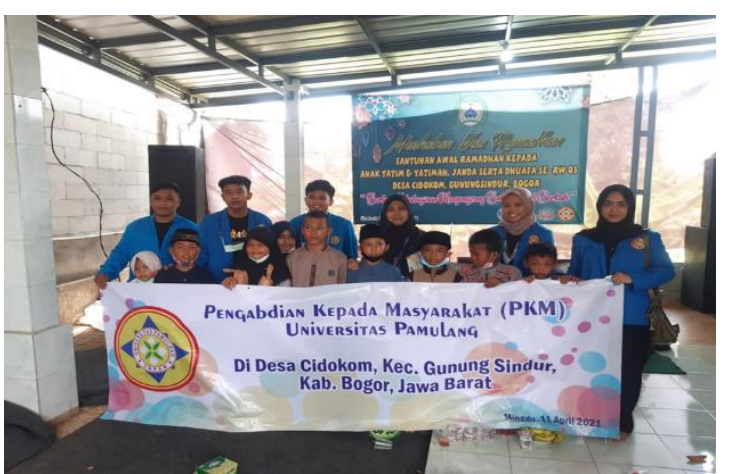

Gambar 3. Kelompok Mahasiswa dan dosen pembimbing yang mengadakan PKM

\section{PENUTUP \\ KESIMPULAN DAN SARAN}

Peran penting Pelatihan Strategi

Bersaing SDM di Era 5.0 Pada Masyarakat Desa dengan jelas telah ditunjukkan secara yurudis, formal dan praktik empiris operasional. SDM yang diperlukan dalam bidang pendidikan adalah SDM yang berkualitas dalam berfikir dan berbuat. Artinya SDM yang menguasai IPTEK dan mengembangkannya sehingga mereka memiliki kemampuan secara konseptual dan kemampuan teknis yang dapat disumbangkan bagi peningkatan kualitas proses dan produk pendidikan. Untuk itu, sangat penting upaya pengembangan SDM agar dapat menunjukkan peran penting dan strategis pendidikan dalam transformasi sosial.

Pengembangan SDM adalah upaya peningkatan kualitas tenaga kependidikan,melalui pendidikan dan pelatihan.Terdapat dua jenis pengembangan SDM, yaitu pengembangan secara formal dan secara informal. Kedua jenis pengembangan SDM tersebut dalam kenyataannya tidak bersifat dikotomis, melainkan saling melengkapi sebagai suatu upaya peningkatan kualitas SDM. Terdapat lima domain penting dalam pengembangan SDM bidang pendidikan, yaitu: profesionalitas, daya kompetitif, kompetensi fungsional, keunggulan partisipatif, dan kerjasama. Pengembangan pada kelima domain tersebut diperlukan upaya pengendalian mutu terpadu atau Total Quality Control (TQC). Selain itu, pendidikan dan latihan sebagai wahana pengembangan SDM diperlukan suatu program diklat terpadu agar tercapai efektivitasnya.
Berdasarkan hasil penelitian dan pembahasan di atas penulis menyarankan sebagai berikut:

1. Untuk Organisasi karang taruna

Sebagai organisasi karang taruna diharapkan dapat menjadi pelopor dalam setiap program pelatihan yang diselenggarakan di lingkungan Desa baik itu dari pemerintah daerah, dari pihak swasta, ataupun dari berbagai lembagalembaga yang lainnya. Selanjutnya kepada karang taruna kami harapkan bisa memperikan contoh sekaligus berbagi pengalaman kepada masyarakat yang lain tentang pengembangan SDM di era 5.0.

2. Untuk Masyarakat

Masyarakat dihimbau agar lebih sadar dan memahami akan pentingnya pengembangan SDM di era 5.0 sekarang ini karena seiring perkembangan zaman akan banyak sekali tantangan-tantangan yang harus dihadapi oleh masyarakat desa, sehingga masyarakat desa sudah siap untuk menghadapinya. Dengan pola pikir yang maju diharapkan masyarakat desa bisa menciptakan UMKM - UMKM yang bisa membangkitkan perekonomian di lingkungan masyarakat.

\section{DAFTAR PUSTAKA}

Ajimat, A., Sunarsi, D., \& Sidiq, F. (2020). Berwirausaha Memanfaatkan Media Sosial Pada Daerah Sepatan. ADI Pengabdian Kepada Masyarakat, 1(1), 69-76.

Harususilo, Yohanes Enggar. 2019. “5 Program Ini Membangun SDM Unggul Indonesia di Era Industri 4.0", https://www.google.co.id/amp/s/amp .kompas.com/edukasi/read/2019/03/ 13/19300891/5-program-inimembangun-sdm-unggul-indonesia-diera-industri-40, diakses pada 9 April 2021.

Hendriyanto, Kumi Laila. 2021. "Menyiapkan Pendidik Profesional Di Era Society 5.0", http://ditpsd.kemdikbud.go.id/artikel /detail/menyiapkan-pendidikprofesional-di-era-society-50, di akses pada 9 April 2021.

Kho, Budi. 2019. "Pengertian Perencanaan SDM ( Sumber Daya Manusia) dan 
Tahapannya",

Paeno, P., Kasmad, K., Sunarsi, D., Maddinsyah, A., \& Supiyan, D. (2020). Pemanfaatan Sampah Plastik Untuk Kerajinan Rumah Tangga Taman Belajar Kreatif Mekar Sari. BAKTIMAS: Jurnal Pengabdian pada Masyarakat, 2(1), 57-61. pengertian-perencanaan-sdm-sumberdaya-manusia-tahapan-perencanaansdm/, di akses pada 10 April 2021.

Ramadhayanti, Ana. 2020. "Membangun Sumber Daya Manusia Unggul Dalam https://ilmumanajemenindustri.com/ Rangka Menghadapi Era Revolusi Industri 4.0 dan Society 5.0", http://news.bsi.ac.id/membangunsumber-daya-manusia-unggul-dalamrangka-menghadapi-era-revolusi

Sunasi, D., Kusjono, G., \& Nuryana, I. (2019). Pelatihan Manajemen Penguasaan Kelas Dan Pembuatan Bahan Ajar Bagi Tenaga Pengajar Sukarela Taman Belajar Kreatif Mekarsari. Jurnal Pengabdian Dharma Laksana, 2(1), 4144. 